\title{
REAL ESTATE MARKET STRUCTURE: INDUSTRIAL ORGANIZATION PERSPECTIVES
}

\author{
MUHAMMAD RIDHUAN BOS ABDULLAH \\ School of Economics, Finance and Banking \\ Universiti Utara Malaysia
}

\begin{abstract}
Existing studies of housing markets assume that property developers is a homogenous, perfectly competitive industry. It concentrates on advanced economies and the impacts of market conditions, regulatory constraints, production characteristics, institutional structure and land supply. Motivated by these circumstances and fewer literature on concentration studies in Malaysia we try to bridging the gap. This paper utilized 5-digit firm level industry data of the Malaysian Standard Industrial Classification (MSIC, 2008) on the average size of property developer establishments and market concentration to test the appropriateness of this paradigm. Our concentration ratio (CR4) results show Malaysian real estate services are considered as competitive market.
\end{abstract}

Keywords: Concentration, competition, market power, real estate services. JEL: L1, L11, L85

\section{Introduction}

In line with the country's aspirations towards a high-income status by 2020, both the government's and the industry's approach to housing provision have evolved significantly in recent years. Recently, the debate is shaped by concerns about housing affordability, particularly for the middle-and lower-middle-income groups, and this has impacted legislation, planning policy, economic development, as well as the industrial organization of the industry.

Challenges facing the industry are plenty, both on the demand and the supply sides (REHDA, 2013). On the demand side, the major issues confronting the industry are the widening affordability gap and a lack of demand for properties meant for certain target groups, including low-cost housing and Bumiputera-designated units. 
Supply (in terms of number of units completed) is inadequate and the mismatch in pricing and location has translated into over-demand in some locations and for specific types of housing.

\section{Real Estate Market Structure}

What is industrial organization (IO)? Simply put, IO is that branch of economics that is concerned with the study of imperfect competition. A market described as less than perfectly competitive leaves open wide possibilities. It could be a duopoly market with only two firms, or perhaps a market dominated by one large firm competing with many very small ones. The products of the different firms may be identical, as in the case of residential developers, or highly differentiated, as in the case of electrical \& electronic appliances. Entry by new firms may be easy, as in the contractor business, of difficult, as in the automobile industry. This variety of possible market characterizations makes it difficult to make broad, unambiguous statements about imperfectly competitive markets.

In some economic sectors, such as manufacturing, (E\&E), business services (Accountants), F\&B (fast food restaurants), industry structure and its consequences are the subject of policy, news and scholarly attention. By contrast, there has been little policy or scholarly interest in the structure of the (real estate) development industry even though it is a highly regulated, high value industry that shapes the industry. Mohd Isa, Tan Pek Voon, Shanti and Nasir (2010) reported that the real estate industry plays an important role in the Malaysian economy. In 2000, a study conducted by the Economic Planning Unit of the Prime Minister's Department demonstrated that a RM1.0 million investment in the housing sector resulted in a total multiplier effect of RM1.469 million for the whole economy. In addition, the real estate industry is said to have strong linkages to more than 140 industry and major sources of employment.

Little is known about the organization of the industry and its implications for matters such as efficiency, the structure of the building industry, and the relationship of the industry with regulations. This neglect is lamentable and the article aims to show that the development industry structure is an important topic demanding attention. It does this by organizing existing literature to outline some possible or likely implications of industry structure, for real estate industry (policy-maker, developers, academics) emphasizing particularly the consequences for a concentrating industry. These 
potential consequences are of importance and wide ranging, concerning, amongst other things; the price and the nature of the real estate industry, the nature of planning, relations between planners and developers, sustainability and even the viability of planning as a government public policy. ${ }^{1}$ Useful study by Malpezzi and Mayo (1997) which analysed two separate but related issues on the effects of government interventions, taxes, subsidies, and regulations, and an aggregate analysis of housing-supply behaviour. The interventions analysis demonstrates that the costs of regulatory and pricing restrictions far outweigh the benefits of subsidies and regulatory exemptions. The aggregate supply model demonstrates the effects of such regulations on market prices and shows, using comparisons of the US, Thailand, and Korea, that countries with more stringent regulatory environments have less elastic supply of housing.

\section{Industrial Organization and the Structure of Industry}

The structure-conduct-performance, hereafter the SCP framework (Table 1) in the field of industrial economics consists of the structure of an industry which influences the conduct or behaviour of that industry, which in turn influences the performance of that industry, and that these dimensions also influence each other. The relation between IO and "conventional microeconomics" has changed over time (Aiginger, Mueller, \& Weiss, 1998). IO became a specific economic field primarily because economics could not handle the economies of scale, the presence of large firms, and product differentiation (Andrew, 1952). The distance to microeconomics grew pronounced, as the empirical strand became dominant, while microeconomics increasingly emphasized optimization, mathematics and formal models. In the eighties, IO accepted that the decision-makers in firms started out with an optimization problem, and then took the lead in promoting the concept that in a world of a few firms, strategic interactions were a crucial part of the story. Firms do not optimize in a given framework of exogenous variables, but in an environment in which other firms are, at the same time, practising the same exercise. IO modelled decisions as non-cooperative games, and exported this approach into other fields of economics.

Ball (2003), states that house builders are characterized by the existence of a large number of relatively small firms. They also use production techniques that are labour-intensive and change relatively slowly. They also are 'flexible' in order to be able to adapt to potentially large variations in output. Generally, as a result, scale economies are low, 
which helps both to make the entry and the exit from the industry relatively easy and to explain the small average firm size.

Healey and Barret (1990) argued that the way in which land and property are themselves 'produced' and consumed entered into the processes of economic production and consumption. Understanding these processes is thus a necessary task, both to assist in the practical activities of urban management and property development and economic development, and to develop a critical capacity to evaluate such practices. They adopted the approach by Giddens (1984), who argued for a relational approach between structure and agency in which 'structure' established by the way agents operate: deploying, acknowledging, challenging and potentially transforming resources, rules and ideas as they frame and pursue their own strategies. Healey and Barret (1990) added that structure, in terms of the framework within which individual agents make their choices, may be seen to inhere in the various resources to which agents may have access, the rules which they consider govern their behaviour, and the ideas which they draw upon in developing their strategies.

Mohd Isa et al. (2010) added that the housing development industry is fragmented and dominated by small and medium-sized firms. They depend on the purchasers' deposits and progress payments to roll the capital and stay in business. With this inclination, their motivation to build continues despite the unsold housing situation in the market. Compared to UK, the housing industry experienced a restructuring process where companies merged and there were take-overs of the smaller and weaker companies in the past two decades. Housing development companies emerged more diversified and operated in more than one property sector.

Table 1

Relationship between Industry Structure, Conduct and Performance

\begin{tabular}{|c|c|c|}
\hline Structure & $\begin{array}{l}\text { Conduct } \\
\text { (Behaviour } \\
\text { of firms in an } \\
\text { industry) }\end{array}$ & $\begin{array}{l}\text { Performance } \\
\text { (How market performs under } \\
\text { different structures) }\end{array}$ \\
\hline Number of firms & Pricing strategies & Allocative efficiency \\
\hline Size distribution of firms & Product strategies & Production efficiency \\
\hline Cost structures & Advertising & Rate of technological advance \\
\hline
\end{tabular}

(continued) 
IJMS 22 (1), 57-72 (2015)

\begin{tabular}{lll}
\hline Structure & $\begin{array}{l}\text { Conduct } \\
\text { (Behaviour } \\
\text { of firms in an } \\
\text { industry) }\end{array}$ & $\begin{array}{l}\text { Performance } \\
\text { (How market performs under } \\
\text { different structures) }\end{array}$ \\
\hline Product differentiation & R\&D & Quality \& services \\
Vertical integration & Plant investment & Equity \\
& Collusion & \\
& Mergers & \\
& Legal strategies & \\
\hline
\end{tabular}

Sources. Scherer \& Ross (1990)

Structure describes the characteristics and the composition of the markets and industries in an economy. At its most aggregated level, it relates to the relative importance of the broadly defined sectors of the economy (Ferguson \& Ferguson, 1994). Here the focus is on the relative sizes of (and trends in) the primary (agriculture and the extractive industries), secondary (industrial) and tertiary (service) sectors. Secondly, structure can refer to the number and size distribution of the firms in the economy as a whole. Structure also relates to the importance and characteristics of individual markets within the economy. This is the sense of the term within the SCP approach. It can be identified by considering the number and size distribution of buyers and sellers (market concentration), the extent to which products are differentiated, barrier to entry conditions, and the extent to which firms are integrated or diversified.

High perceptions of the development industry structure are either of a competitive industry or of one dominated by large powerful players. In a sense both perspectives are partly correct. Johnstone (1984) argued that housing is a very speculative industry, and the housing development industry has always been known as a rich man's "game". According to the report by JPPH (Property Market Report, 2013), 381,130 transactions worth RM152.37 billion were registered in 2013 against 427,520 transactions worth RM142.84 billion in 2012. The residential sub-sector retained the lion's share in the property market, contributing $64.6 \%$ share in volume and $47.3 \%$ in value. The year registered 246,225 residential property transactions worth RM72.06 billion. Housing units made up the majority with $81.9 \%(201,645$ units) of the market share. Terraced houses, being the most popular, contributed $38.8 \%$ (95,536 units) of residential transactions.

The law applicable to housing developers in Peninsular Malaysia is the Housing Developers (Control and Licensing) Act, 1966 (Act 118), which came into force on August 29, 1969. The Act does not apply 
to Sabah and Sarawak. Apart from the 1966 Act, the law governing housing development in West Malaysia is contained in the two regulations of 1989 and 1991. The Act does not apply to any society registered or incorporated under any written law relating to cooperative societies. This means that housing projects undertaken by co-operative bodies are not governed by the 1966 Act. The Act also does not apply to housing projects undertaken by any statutory body or agency of the federal or state governments. Thus, housing projects undertaken by such agencies as the state economic development corporations (SEDCs) are not governed by this Act.

Before a housing developer can develop a piece of land, certain procedures must be followed. These procedures can either be legal, such as conforming to the requirements of the National Land Code and other related laws, the Planning Act or the Environmental Quality Act, or the conformity might be in the form of administrative regulations or directives given by the government to fulfill certain policy objectives. This being the case, before a piece of land is developed with buildings put up on the land, certain legal and administrative procedures must be resolved, or else the developer or the landowner will face legal and administrative issues. The mistakes can be costly for the developer. Litigation in court might take a few years before the issues are finally decided. Any land development to be carried out by the private sector must be on alienated land, that is, land with a land title issued by the land office on behalf of the state authority. On alienation by the state authority, the land will be subjected to either one of the categories: agriculture, building or industry.

Keogh and D'Arcy (2002) examine property development from an institutional economic perspective. Their main focus is the property market as an institution, i.e. as a set of formal and informal rules governing the behaviour of the diverse property market actors. Based on their previous works, development is explored in the context of an institutional hierarchy in which three main levels can be identified. First, the property market exists within an institutional framework defined by political, social, economic and legal rules and conventions by which the society in question is organized. At the next level, the property market is itself considered as an institution with a range of characteristics which describe its structure and determine its scope and function. Finally, at the third level, the main organizations that operate in the property market can be considered in terms of the way they are structured and the way they change. The relationship 
between institutions and organizations at each level, and between levels, can best be described as interactive, defined in relation to one another and capable of change in response to action and experience.

\section{Concentration in Real Estate Market}

Any analysis of a firm's competitive environment involves identifying the key elements of industry structure. The most important characteristics of industry structure include the number and size distribution of firms, the existence and height of barriers to entry and exit, and the degree of product differentiation (Curry \& George, 1983; Shepherd, 1982; Abdullah \& Suhaila, 2006). Seller-concentration, an indicator of the number and size distribution of firms, can be measured at two levels:

1. All firms that form part of an economy, located within some specific geographical boundary;

2. All firms classified as members of some industry or market, again located within some specific geographical boundary (Table 2, MSIC 2008).

Throughout much of microeconomics and IO, the terms "market" and "industry" tend to be used rather loosely, and sometimes interchangeably. Although the distinction is not rigid, it seems natural to use the term "industry" to refer specifically to a market's supply side or productive activities, while the term "market" encompasses both supply/production, and demand/consumption (Lipczynski, Wilson, \& Goddard; 2005). Kay (1990) sees markets as representing demand conditions, while industries represent supply conditions. In Kay's terminology, the strategic market, defined as the smallest geographic or product area in which a firm can successfully compete, brings the industry and market together.

Two measures of concentration take both the number of firms and the distribution of market share into account. The first is the concentration ratio and the latter is an index called the Herfindahl-Hirschman Index (HHI). ${ }^{2}$ We used the 4 -firm concentration ratio, as they are fairly easily understood indices of market power. Nonetheless it is not our intention here to discuss the limitation of such measures. A value close to zero would indicate that the largest $K$ firms supply only a small share of the market; 100 per cent could indicate a single supplier. 
The concentration ratio is the cumulative share of the $\mathrm{K}$ largest firms in the market, where here we chose four-firm concentration ratio (CR4) and measured by sales from the total transaction of property in 2010 and 2013.

$$
C R K=\sum_{i=1}^{K} S i
$$

Where CRK = the Kith firm concentration ratio

si = the percentage market share of the $i$ th firm

There are no set rules for the choice of $K$, the number of large firms to be included in the calculation of $\mathrm{CR}_{\mathrm{k}}$.

White (1981) discusses the criteria for the appropriate measurement of firm size:

In the case of concentration in individual markets, we are searching for some inferences as to the likelihood of oligopolistic co-ordination concerning prices and sales. The (sales) shares of the oligopolists themselves will be a prime determinant of the likelihood of that co-ordination. Hence, industry sales are the proper measure of concentration calculations in individual industries.

The specific standards used for the four categories are familiar in the literature (Shrerer, 1980; Kaysen \& Turner, 1959), as follows:

1. Pure Monopoly: Market share at or near $100 \%$, plus effectively blockaded entry, plus evidence of effective monopoly control over the level and structure of prices. In practice this includes mainly certain utilities and patented goods.

2. Dominant Firms: A market share of $50 \%$ to over $90 \%$, with no close rivals. A high entry barrier. An ability to control pricing, to set systematic discriminatory prices, to influence innovation, and (usually) to earn rates of return well above the competitive rate of return.

3. Tight Oligopoly: Four-firm concentration above $60 \%$, with stable market share. Medium or high entry barriers. A tendency toward cooperation, shown especially by rigid prices. Excess profits are neither necessary nor sufficient to establish the existence of tight oligopoly. As a special case, governmentregulated firms which are able exert some degree of market 
power rather than be wholly passive to regulation are included here. Also included are markets where the government assists collusion, even if the market's concentration is low.

4. Effective Competition: Four-firm concentration below $40 \%$, with unstable market shares and flexible pricing. Low entry barriers, little collusion, and low profit rates.

\section{The Data (5-digit; MSIC 2008)}

Following MSIC, Section L real estate activities include acting as lessors, agents and/or brokers in one or more of the following: selling or buying real estate, renting real estate, providing other real estate services such as appraising real estate or acting as real estate escrow agents. Activities in this section may be carried out on own or leased property and may be done for a fee or on contract basis. Also included is the building of structures, combined with maintaining ownership or leasing of such structures.

Table 2

Real Estate Activities with Own or Leased Property (CR4 2010 \& 2013)

\begin{tabular}{llr}
\hline Item & Description & $\begin{array}{c}\text { CR4 }<40 \% \\
2010 \quad 2013\end{array}$ \\
\hline 68101 & $\begin{array}{l}\text { Buying, selling, renting and operating self-owned or leased } \\
\text { real estate-residential building }\end{array}$ \\
68102 & $\begin{array}{l}\text { Buying, selling, renting and operating self-owned or leased } \\
\text { real estate-non residential buildings }\end{array}$ \\
68103 & $\begin{array}{l}\text { Buying, selling, renting and operating self-owned or leased } \\
\text { real estate-land }\end{array}$ \\
68104 & $\begin{array}{l}\text { Development of building projects for own operation, i.e. } \\
\text { renting of space in these buildings }\end{array}$ \\
68109 & Real estate activities with own or leased property n.e.c. ${ }^{3}$ & \\
\hline
\end{tabular}
Sources. Adaption from Statistics Dept. of Malaysia (2014)

(1) Includes: offices, shop houses, industrial units, exhibition halls, space in theatres, self-storage facilities, malls and shopping centres

(2) Includes: providing homes and flats, apartments or condominiums for more permanent use (monthly or annual)

(3) Includes: (a) provision of space for animal boarding only

(b) operation of government owned

(c) subdividing real estate into lots, without land improvement

(d) operation of residential mobile home sites 
Table 2 shows that our finding on 4-firm concentration ratio for 2010 and 2013 is less than $40 \%$. It has not changed much from 2010 to 2013 for real estate activities with own or leased property. Shepherd (1982) concluded that four-firm concentration below $40 \%$ was an effective competition with unstable market shares and flexible pricing, low entry barriers, little collusion, and low profit rates. For the level of the 5-digits 68101 with buying selling, renting and operating selfowned or leased real estate-residential building was within effective competition (below 40\%).

The five-digit industry concept was selected because it closely approximates the theoretical definition of an industry. The objective of an industrial classification system is to classify data in respect of the economy according to the categories of activities and the characteristics which are similar. MSIC is a classification of the kinds of economic activity and not a classification of goods and services or a classification of occupations.

Geithman, Marvel and Weiss (1980) argued that the critical concentration ratio can take two forms. The most common notion is that at some level of concentration, industries become effectively collusive so that profit rates, price-cost margins, or prices rise to monopolistic levels. An alternative is that at some level of concentration they begin to affect performance. Below that level there is no relationship between concentration and performance, but above that level profits, margins, and/or prices rise with concentration.

Furthermore, according the neoclassical theory, the greater the number of firms and the more uniform they are in size, the greater the degree of competition is likely to be present. Internationally, the industry varies considerably in its degree of concentration (Buzzelli, 2001).

The initial capital outlay to enter the housing production business is viewed lower than any other production businesses (Mohd Isa et al., 2005). Jaafar and Ali (2011) studied on indigenous developers and they found that a majority of them preferred to develop medium-cost houses in sub-urban areas. This findings showed that the sampled indigenous housing developers in Malaysia were more inclined to develop medium-cost houses, in particular single and double-storey terrace houses. Even the state corporations have shown interest in constructing medium and high-cost houses, albeit their major role is to actually construct and distribute low-cost houses (Agus, 1997). 
Somerville (1999) points out that the traditional approach in housing-market analysis assumes that new residential structures are supplied by a perfectly competitive homebuilding industry. Researchers point to the large number of builders and the small share of the national market held by the country's largest builders to support this assumption. His results are more consistent with treating homebuilders as monopolistically competitive suppliers of a differentiated product than treating them as perfectly competitive homogenous firms. Builders are larger in more active housing markets and where there is a greater supply of readily developed land suitable for large developments.

In Europe, for example, housebuilding is more concentrated than in North America, though still much less than in other industries. Housebuilding in Britain and Europe is more concentrated than in North America because of the use of more capital-intensive building methods requiring large-firm resources, and the greater reliance on large-scale state contracts. This explains why, in places such as Australia, housebuiling is more like that in North America, where smaller firms are better represented.

Beck, Scott, and Yelowitz (2012), argued that at the national level (US), both the NAR and the FTC/DOJ reports point out that the industry is not concentrated. But their added, real estate markets are local, so national-level market structure information is not dispositive. To determine whether supplier concentration at the local market level creates the potential for softer competition and price rigidity, data on the number and size shares of firms in local markets are required.

Akintoye and Skitmore (1991) undertook an analysis of company accounts from 1980 to 1987, which segmented construction firms into contractors and housebuilders and examined the effect of size on returns. Three important conclusions were derived from their analysis: (a) The profitability of contracting was found to be generally low and fairly constant at around 3\% when measured as a ratio of turnover. This they attributed to 'excessive' competition, though 'excessive' is not defined, (b) housebuilders' returns were greater than in contracting because of the greater risks and need for working capital and (c) larger firms had persistently higher rates of return which they attributed to greater managerial efficiency.

The work of Hui, Ooi, and Wong (2007) found that Hong Kong property companies that diversified into other sectors appeared 
to perform better than those focused solely in real estate. Property companies in Hong Kong generally achieved higher rates of returns on their capital invested than Singapore property companies.

\section{The Consequences and Competition}

The number of housing developers has increased over the years, thereby fostering competitive environment in the industry. Based on the Economic Census (2011) results, a total of 8,277 establishments were operating in real estate services in Malaysia. Real estate activities with own or leased property had the highest number of establishments, 6,934 or 83.8 per cent. Kuala Lumpur $(2,557)$, Selangor $(1,820)$ and Johor (914) registered the highest number of establishments. Size of firm varied widely by value of gross output. Nearly 71 per cent of the value of gross output was produced by the largest developers.

Table 3 shows the principal statistics of real estate service activities by output size in 2010. The largest firm consisting of output size of RM10, 000 million and above contributed almost $70 \%$ of the total value. The number of establishments were high within the output size of RM5 million to RM500 million. In Malaysia, the private sector has been the principal player since the late 1950s (Lim, 1997; Shuid, 2004). The increase in the private sector housing delivery had in part been helped by the increase in the number of housing developers. To get listed on the Bursa Malaysia (previously known as the Kuala Lumpur Stock Exchange), a company needs to meet certain requirements. For housing developers, they are required to possess a minimum land bank of 1,000 acres, have sufficient on-going property development projects, and obtain an aggregate after-tax profit of not less than RM30 million for the five full years (Ting, 2002).

According to the basic theory of market structure, higher concentration will increase the firm's profit which will be followed by higher price thus increasing market power. Empirical studies often reveal that the association of profit and market concentration is due to the 'ability' of firms to influence price levels. In other words, the more concentrated an industry is, the better for it to become monopolistic with higher price-cost margin or profits, which can gradually enhance marketpower of the industry.

The neoclassical analysis traditionally shows that monopoly leads to an inferior allocation of resources by restricting output below the competitive level. An optimal allocation of current resources 
requires the output to be increased until the marginal benefit derived by consumers equals the marginal cost of production. However, it is argued that this level of output will not be attained because the monopolist maximizes profit by equating marginal cost with marginal revenue. As a result there is a reduction in consumer surplus and deadweight welfare loss to society.

Table 3

Principal Statistics of Real Estate Service Activities by Output Size, 2010

\begin{tabular}{|c|c|c|c|c|c|c|}
\hline $\begin{array}{l}\text { Ouput } \\
\text { size }\end{array}$ & $\begin{array}{c}\text { Number of } \\
\text { establishments }\end{array}$ & $\begin{array}{l}\text { Value } \\
\text { of gross } \\
\text { output }\end{array}$ & $\begin{array}{c}\text { Value of } \\
\text { intermediate } \\
\text { Input }\end{array}$ & $\begin{array}{l}\text { Value } \\
\text { added }\end{array}$ & $\begin{array}{c}\text { Salaries } \\
\text { and } \\
\text { wages } \\
\text { paid }\end{array}$ & $\begin{array}{l}\text { Value of } \\
\text { fixed assets } \\
\text { owned as at } \\
\text { the end of } \\
\text { the year }\end{array}$ \\
\hline$\left(\mathrm{RM}^{\prime} 000\right)$ & & $\left(\mathrm{RM}^{\prime} 000\right)$ & $\left(\mathrm{RM}^{\prime} 000\right)$ & $\left(\mathrm{RM}^{\prime} 000\right)$ & $\left(\mathrm{RM}^{\prime} 000\right)$ & $\left(\mathrm{RM}^{\prime} 000\right)$ \\
\hline Total & 8,277 & $18,648,494$ & $7,130,646$ & $11,517,848$ & $1,579,880$ & $46,762,854$ \\
\hline Below 5 & 95 & 257 & 191 & 66 & 1,355 & 53,677 \\
\hline $5-<100$ & 2,594 & 11,9966 & 55,342 & 64,624 & 69,188 & $1,989,199$ \\
\hline $100-<200$ & 1,376 & 19,7697 & 78,211 & 119,486 & 71,271 & $1,741,297$ \\
\hline $200-<500$ & 1,680 & 535,399 & 207,170 & 328,229 & 146,633 & $2,973,257$ \\
\hline $500-<1,000$ & 848 & 59,5004 & 210,126 & 384,878 & 146,633 & $3,027,087$ \\
\hline $1,000-<5,000$ & 1,126 & $2,418,312$ & 836,027 & $1,582,285$ & 347,713 & $8,024,859$ \\
\hline $5,000-<10,000$ & 230 & $1,586,012$ & 570,664 & $1,015,348$ & 154,904 & $5,681,237$ \\
\hline $10,000-<$ and above & 328 & 13,195847 & $5,172,915$ & $8,022,932$ & 661,722 & $23,272,241$ \\
\hline
\end{tabular}

Sources. Adapted from Economic Census (2011)

\section{Conclusion}

Left to itself, real estate service activity would be a highly competitive industry. However, for the last few years, two issues have hogged market-affordability and the steep rise in prices in the landed residential sector, which subsequently spilled over to the highrise condominium market in the Klang Valley and in other cities. Developers argued that the sharp price hike of properties after 2006 was due to a convergence of factors starting with a steep hike in the cost of building materials. Steel bars went up from RM1,500 per tonne to peak at RM3,800 before settling at about RM2,500. Similar steep price hikes were felt for cement, bricks and sand apart from related raw materials including fuel. At the same time land prices also appreciated steeply over the past decade. With regulations 
for the sustainablity of real estate industry, the Housing and Local Government Ministry and the relevant authorities can play a greater role in controlling prices. In Singapore, Germany, South Korea and Australia, the authorities study the housing needs of their peoples.

\section{End Notes}

${ }^{1}$ This article makes no claim to be an exhaustive or definitive statement on these issues. Instead, the hope is to draw attention to this issue, to stimulate research and debate, and to encourage both practitioners and scholars to reflection upon the implications of inaction.

2 A typical measure of industrial concentration. CR4 are used in this study. See Curry and George (1983) for an overview of measures of industrial concentration.

\section{References}

Abdullah, M. R. B., \& Suhaila, A. J. (2006). Industrial structure and concentration in Malaysian manufacturing industry. International Journal of Management Studies, 13, 83-101.

Agus, M. R. ( 1997). Historical perspective on housing development. In Mohd-Don, A. (Ed.), Housing the nation: A definitive study. Kuala Lumpur: Cagamas.

Aiginger, K., Mueller, D. C., \& Weiss, C. (1998). Objectives, topics and methods in industrial organization during the nineties: Results from a survey. International Journal of Industrial Organization, 16, 799-830.

Akintoye, A., \& Skitmore, M. (1991). Profitability of UK construction contractors. Construction Management and Economics, 9, 311-325.

Andrew, P. W. S. (1952). Industrial economics as a specialized subject. Journal of Industrial Economics, 1, 72-79.

Ball, M. (2003). Markets and the structure of the housebuilding industry: An international perspective. Urban Studies, 40(5-6), 897-916.

Beck, J., Scott, F., \& Yelowitz, A., (2012) Concentration and market structure in local real estate markets. Real Estate Economics, 40, $422-460$.

Buzzeli, M. (2001). Firm size structure in North American housebuilding: Persistent deconcentration, 1945-1998. Environment and Planning, 33, 533-550.

Curry, B., \& George, K. (1983). Industrial concentration: A survey. Journal of Industrial Economics, 31, 205-256. 
Department of Statistics, Malaysia. (2014). Economic Census 2011: Business Services. Kuala Lumpur: Putrajaya.

Department of Statistics. (2008). Malaysian Standard Industrial Classification 2008 Ver.1. Kuala Lumpur: Putrajaya.

Ferguson, P. R., \& Ferguson, G. J. (1994). Industrial economics: Issues and perspectives (2rd ed.). New York: New York University Press.

Geithman, F. E., Marvel, H. P., \& Weiss, L. W. (1980). Concentration, price, and critical concentration ratios. Review of Economics and Statistics, 61, 346-353.

Giddens, A. (1984). The constitution of society. London: Polity Press.

Healey, P., \& Barret, S. (1990). Structure and agency in land and property development processes, Urban Studies, 27(1), 89-104.

Hui, E. C. M., Ooi, J. T. L., \& Wong, K. (2007). Economic performance of property companies in Hong Kong. Journal of Property Research, 24(2), 139-157.

Jaafar, M., \& Ali, R. (2011). A study on indigenous housing developers in Malaysia. African Journal of Business Management, 5(16), 68916900.

Johnstone, M. (1984). Urban housing and housing policy in Peninsular Malaysia. International Journal of Urban Regional Research, 8(4), 497-529.

Kay, J. A. (1990). Vertical restraints in European competition policy. European Economic Review, 34, 551-561.

Kaysen, C., \& Turner, D. F. (1959). Antitrust policy. Cambridge: Harvard University Press.

Keogh, G., \& D'Arcy, E., (2002). The market context of property development activity. Development $\mathcal{E}$ developers: Perspectives on property. London: Blackwell Publishing.

Lim, C. S. J. (1997). Housing and the environment. A planner's perspective in housing the nation: A definitive study. Kuala Lumpur: Cagamas.

Lipczynski, J., Wilson, J., \& Goddard, J. (2005). Industrial organization (2nd ed.).London: Prentice Hall.

Malpezzi, S., \& Mayo, S. K. (1997). Getting housing incentives right: A case study of the effects of regulation, taxes, subsidies on housing supply in Malaysia. Land Economics, 73(3), 372-391.

Mohd Isa, Z., Tan Pek Voon., Shanti Rani, \& Nasir, A. M. (2010). Housing market performance: A comparative study between Malaysia, England and Korea. $4^{\text {th }}$ NAPREC Conference, INSPEN, Kuala Lumpur.

Property Market Report. (2013). Ministry of Finance. Kuala Lumpur: Putrajaya. 
IJMS 22 (1), 57-72 (2015)

REHDA. (2013). Challenges and changes in the industry. In Cagamas (Ed.), Housing the nation: Policies, issues and prospect. Kuala Lumpur: Cagamas.

Scherer, F. M. (1980). Industrial market structure and economic performance (2rd ed.). Chicago, IL: Rand McNally.

Scherer, F. M., \& Ross, D. (1990). Industrial market structure and economic performance (3rd ed.). Boston: Houghton Mifflin.

Shepherd, G. W. (1982). Causes of increased competition in the U.S. economy, 1939-1980. The Review of Economics and Statistics, 64(4), 613-626.

Shuid, S. (2004). Low medium cost housing in Malaysia: Issues and challenges. In Asia Pacific Network for Housing Research (APNHR) Conference 2004, University of Hong Kong, Hong Kong China.

Somerville, C. T. (1999). The industrial organization of housing supply: Market activity, land supply and the size of homebuilder firms. Real Estate Economics, 27(4), 669-694.

Ting, K. H. (2002). Listed property companies in Malaysia: A comparative performance analysis. In Seventh Annual Pacific Rim Real Estate Society Conference 2002, Christchurch, New Zealand.

White, L.J. (1981). What has been happening to aggregate concentration in the United States. Journal of Industrial Economics, 29, 223-230. 